\title{
INTRODUKSI TEKNIK BUDIKDAMBER DAN PENGOLAHAN IKAN ZERO WASTE DI DESA PULAU SEMAMBU INDRALAYA
}

\author{
Rinto $^{1}$, Mochammad Syaifudin², Ferdiand Hukama Taqwa, Herpandi, Susi Lestari, Indah \\ widiastuti
}

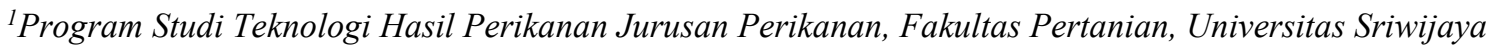
${ }^{2}$ Program Studi Budidaya Perairan Jurusan Perikanan, Fakultas Pertanian, Universitas Sriwijaya

Penulis Korespondensi : rinto@fp.unsri.ac.id

\begin{abstract}
Abstrak
Adanya kasus pandemi COVID-19 menyebabkan berkurangnya pendapatan masyarakat Desa Pulao Semambu. Hal ini disebabkan oleh dua faktor yaitu pertama terhentinya berbagai agenda wisata yang dilakukan di Desa Pulau Semambu yang berimbas pada tidak adanya wisatawan yang membeli hasil panen, serta kedua, meskipun masyarakat masih tetap dapat menjual hasil pertaniannya di Pasar Indralaya, namun pandemi COVID-19 juga menyebabkan daya beli masyarakat menurun. Kebijakan pemerintah untuk work from home (WFH) berimbas pada tutupnya sebagian besar rumah makan yang berada di dalam dan di sekitar Universitas Sriwijaya, dikarenakan tidak adanya mahasiswa yang aktif hadir secara langsung sehingga kebutuhan akan sayuran dari Desa Pulau Semambu menjadi menurun. Tujuan kegiatan ini adalah memberikan informasi teknologi berupa budidaya ikan dengan memanfaatkan ruang pekarangan yang terbatas berupa Teknik budidaya ikan dalam ember (BUDIKDAMBER) serta pengolahan ikan berbasis zero waste. Kesimpulan dari kegiatan ini adalah tema kegiatan pengabdian tehnik budikdamber dan pengolahan ikan berbasis zero waste diterima dengan baik oleh masyarakat Desa Pulau Semambu, aktivitas diskusi dan tanya jawab yang berlangsung seru dan menarik. Paket bantuan berupa 5 unit budikdamber dan 5 unit hand sealer sangat bermanfaat untuk pemanfaatan teknologi secara langsung dari materi yang disampaikan dan diharapkan dapat memacu masyarakat untuk dapat mengaplikasikan ilmu/teknologi yang diperoleh.
\end{abstract}

Kata kunci: Pulau Semambu, budikdamber, zero waste

\section{Pendahuluan}

Desa Pulau Semambu secara administeratif termasuk dalam Kecamatan Indralaya Utara, Kabupaten Ogan Ilir, Propinsi Sumatera Selatan. Sebagian besar, warga Desa Pulau Semambu memiliki mata pencaharian sebagi petani, baik bercocok tanam sayur-sayuran seperti kangkung, bayam, terong, dan cabe serta beternak ayam kampung dan budidaya ikan di dalam kolam (Mukti et al, 2020).

Selama ini Desa Pulau Semambu dikenal dengan Desa Agrowisata, dimana sayur mayur yang ditanam masyarakat di kebun maupun pekarangan sekitar rumahnya menjadi salah satu obyek wisata yang ditawarkan. Para wisatawan dapat secara langsung memetik sayuran maupun menanam sayuran sebagai sarana edukasi terutama bagi para anak-anak. Beberapa paket agroeduwisata yang ditawarkan adalah outbond dan petik sayuran seperti kankung, bayam, terong dan cabe serta menanam sayuran bagi anak-anak. Kondisi ini menjadikan masyarakat terbantukan secara ekonomi dikarenakan sayur-mayur yang ditanam dapat secara langsung dibeli oleh para wisatawan melalui sistem paket wisata yang ditawarkan.

A. Identifikasi dan Perumusan Masalah

Adanya kasus pandemi COVID-19 menyebabkan berkurangnya pendapatan masyarakat Desa Pulao Semambu. Hal ini disebabkan oleh dua (2) faktor yaitu pertama terhentinya berbagai agenda wisata yang dilakukan di Desa Pulau Semambu yang berimbas pada tidak adanya wisatawan yang membeli hasil panen melalui sistem paket wisata yang ditawarkan. Kedua, meskipun masyarakat masih tetap dapat menjual hasil pertaniannya di Pasar Indralaya, namun pandemi COVID-19 juga menyebabkan daya beli masyarakat menurun. 
Kebijakan pemerintah untuk work from home/study from home (WFH/SFH) berimbas pada tutupnya sebagian besar rumah makan/kantin yang berada di dalam dan di sekitar Universitas Sriwijaya, dikarenakan tidak adanya mahasiswa yang aktif hadir secara langsung sehingga kebutuhan akan sayuran dari Desa Pulau Semambu menjadi menurun. Oleh karena itu permasalahan yang dapat teridentifikasi dari masyarakat Desa Pulau Semambu akibat COVID-19 adalah:

a. Menurunnya daya beli hasil pertanian dari masyarakat Desa Pulau Semambu yang berimbas pada penurunan penghasilan masyarakat dan menurunnya daya pemenuhan kebutuhan pokok pangan yang seimbang, yang memenuhi kebutuhan karbohidrat, protein, lemak serta vitamin dan mineral.

b. Pemanfaatan pekarangan rumah belum optimal, meskipun selama ini banyak pekarangan dipergunakan sebagai lahan bercocok tanam namun bisa dikombinasikan dengan kegiatan budidaya ikan sekala rumah tangga, minimal untuk memenuhi kebutuhan keluarga.

c. Belum adanya teknologi yang dikuasi masyarakat terkait teknologi budidaya ikan sekala rumah tangga dan konsep optimalisasi pengolahan produk olahan ikan berbasis zero waste yang menghasilkan produk olahan ikan tahan lama baik untuk konsumsi keluarga maupun untuk dipasarkan/dijual secara langsung maupun melalui sistem online.

\section{B. Kerangka Pemecahan Masalah}

Tiga permasalahan yang teridentifikasi pada masyarakat Desa Pulau Semambu akibat COVID-19 dapat diatasi melalui pendekatan pelaksanaan kegiatan berupa:

a. Memperkenalkan teknik budidaya ikan sekala rumah tangga dalam bentuk BUDIKDAMBER (budi daya ikan dalam ember) yang dapat digunakan untuk budi daya ikan nila maupun ikan lele. Masalah ketersediaan lahan budidaya perikanan, semakin terbatasnya air untuk kegiatan perikanan dapat diatasi dengan bantuan teknologi. Semakin berkurangnya lokasi budidaya yang luas mengharuskan kita semakin kreatif dalam memanfaatkan lokasi yang sempit serta dalam penghematan air budidaya. Budidaya ikan dalam ember "budikdamber" menjadi solusi potensial bagi budidaya perikanan di lahan yang sempit dengan penggunaan air yang lebih hemat, mudah dilakukan masyarakat di rumah masing-masing dengan modal yang relatif kecil serta akhirnya mampu mencukupi kebutuhan gizi masyarakat (Nursandi, 2018).

b. Memperkenalkan teknologi pengolahan ikan berbasis zero waste (tanpa limbah) melalui pembuatan produk abon ikan, bekasam, dan keripik kulit/tulang (Wida dan Anam, 2016; Widyatami et al, 2016).

c. Memperkenalkan teknologi pengemasan yang dapat menyimpan produk perikanan lebih lama/lebih awet.

d. Melakukan pendampingan berupa pengontrolan secara periodik terhadap penerapan teknologi yang telah disampaikan.

\section{Tujuan dan Manfaat Kegiatan}

Tujuan kegiatan pengabdian ini adalah memberikan informasi teknologi berupa budi daya ikan dengan memanfaatkan ruang pekarangan yang terbatas berupa Teknik budidaya ikan dalam ember (BUDIKDAMBER) serta teknologi pengolahan ikan berbasis zero waste.

Manfaat kegiatan ini adalah masyarakat Desa Pulau Semambu memahami Teknik budikdamber dan pengolahan ikan berbasis zero waste sehingga bisa diterapkan untuk memenuhi kebutuhan pangan keluarga di masa pandemi COVID-19 dan sebagai bekal pengetahuan untuk mengembangkan produksi olahan ikan dalam paket agrowisata Desa Pulau Semambu apabila kondisi sudah normal (Tanpa COVID-19).

\section{Metode Pelaksanaan Kegiatan}

A. Khalayak Sasaran

Khalayak sasaran dalam kegiatan ini adalah masyarakat Desa Pulau Semambu berjumlah 30-35 orang yang mewakili rumah tangga masing-masing.

B. Metode Pelaksanaan Kegiatan Pengabdian

Secara rinci metode pelaksanaan kegiatan yang akan dilakukan meliputi:

1. Persiapan sarana dan prasarana pengabdian, meliputi : pembuatan brosur metode budikdamber, pembuatan produk olahan ikan, pengadaan alat dan bahan, dan pembuatan contoh produk

2. Pelaksanaan Sosialisai dan Pelatihan, meliputi: pertemuan dengan peserta, Penyuluhan/pemaparan dan pelatihan teknik budikdamber, penjelasan pengolahan berbasis zero waste dengan materi pembuatan pempek 
Pelangi dan keripik kulit/tulang ikan.

3. Monitoring Kegiatan terhadap aplikasi kegiatan yang disampaikan akan dilakukan secara periodic dengan melihat tingkat keberhasilan budikdamber dan pembuatan produk olahan ikan.

4. Publikasi kegiatan melalui media cetak dan online.

\section{Hasil dan Pembahasan}

\section{A. Persiapan Sarana dan Prasarana}

Persiapan sarana dan prasarana dalam kegiatan pengabdian masyarakat bertemakan teknik budikdamber dan pengolahan ikan berbasis zero waste meliputi persipan baner, materi sosialisasi/penyuluhan, sperangkat alat budikdamber dan sealer packaging untuk pengemasan produk. Selain itu juga dilakukan pengurusan ijin dan perencanaan waktu dan tempat kegiatan dilakukan. Kegiatan pengabdian masyarakat dilakukan pada 24 November 2020 bertempat di Kediaman Kepala Desa Pulau Semambu, Indralaya Utara, yaitu Bapak Mat Tarsan.

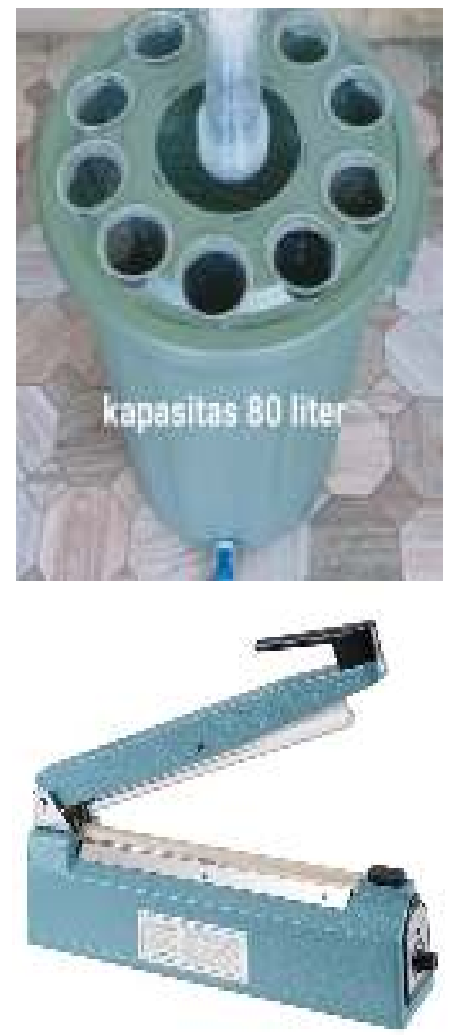

Gambar 1. Satu Unit Alat Budikdamber dan Hand Sealer packaging

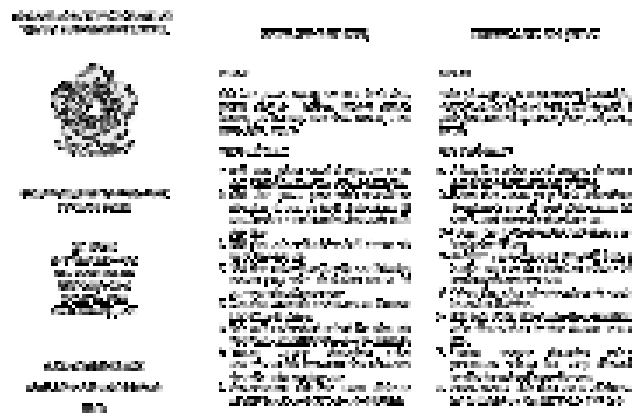

Gambar 2. Leaflet Pembuatan Keripik Sisik dan Keripik Tulang Ikan

\section{B. Pelaksanaan Sosialisasi Kegiatan} Pengabdian Masyarakat 1. Pembukaan Acara Kegiatan

Kegiatan pengabdian masyarakat berupa sosialisasi tehnik budikdamber dan pengolahan ikan zero waste dilaksanakan pada tanggal 24 November 2020. Kegiatan ini dihadiri oleh warga desa Pulau semambu sebanyak 35 orang (Daftar Terlampir) yang merupakan perwakilan tiap-tiap Dusun yang ada di wilayah Desa Pulau Semambu. Kegiatan ini dibuka secara langsung oleh Pembantu Dekan III Bapak Mochammad Syaifudin, S.Pi., M.Si dan Kepala Desa Pulau Semambu Bapak Mat Tarsan. Dalam sambutannya Kepala Desa Pulau Semambu menyatakan sangat berterimakasih kepada Universitas Sriwijaya, khususnya Jurusan Perikanan yang mau memperhatikan warga desanya dengan memberikan informasi maupun pelatihan-pelatihan yang bermanfaat, apalagi di masa Pandemi Covid19 seperti saat ini. Bapak M. Syaifudin, S.Pi., M.Si., Ph.D sebagai wakil Dekan III FP, dalam sambutannya juga menyatakan bahwa kegiatan pengabdian ini dilaksanakan secara rutin oleh Fakultas Pertanian Universitas Sriwijaya dan diharapkan menjadi wadah bagi penerapan teknologi maupun pengetahuan dari para peneliti dan dosen Universitas Sriwijaya. Teknologi yang diperkenalkan pada masyarakat Desa Pulau Semambu yaitu teknik budidaya ikan dalam ember atau yang sering disebut dengan BUDIKDAMBER dan teknik pengolahan ikan zero waste (tanpa limbah) yang memanfaatkan semua bagian ikan, yaitu daging ikan dan limbah ikan berupa jeroan, sisik dan tulang. Teknik Budikdamber dijelaskan secara rinci oleh Bapak Dr. Ferdinan Hukama Taqwa, S.Pi., M.Si, sedangkan pengolahan ikan berbasis zero waste disampaikan oleh Bapak Herpandi, S.Pi., M.Si., Ph.D. 


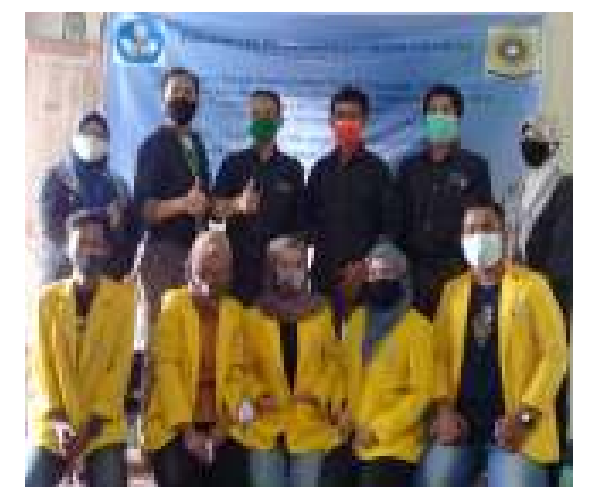

Gambar 3. Tim Pengabdian Masyarakat

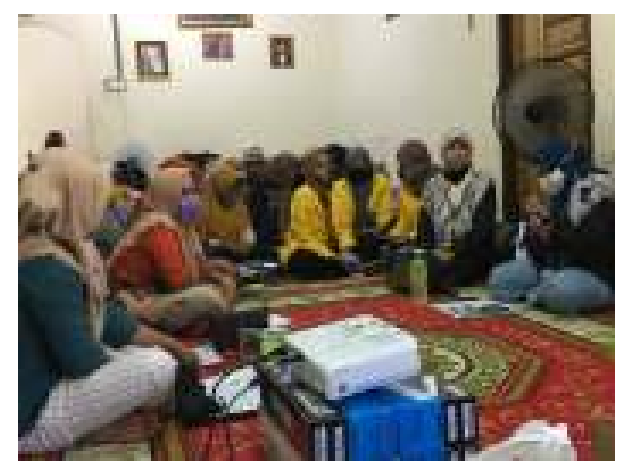

Gambar 4. . Peserta Pengabdian Masyarakat

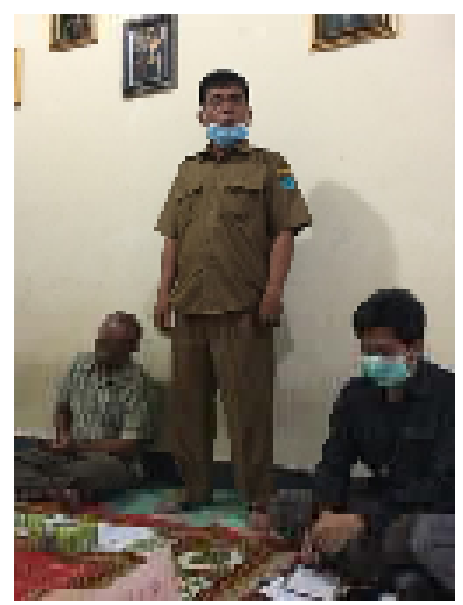

Gambar 5. Sambutan Kepala Desa Pulau Semambu (Bapak. Mat Tarsan).

\section{Penjelasan Tehnik Budikdamber}

Dalam kegiatan ini, Dr. Ferdinan Hukama Taqwa menyebutkan bahwa, teknik budikdamber merupakan teknologi budidaya ikan sederhana yang dapat dilakukan oleh masyarakat. Selain untuk pembesaran ikan, teknik budikdamber juga dapat menghasilkan berbagai jenis sayuran seperti kangkung dan sawi. Tehnik budikdamber terbuat dari bahan-bahan yang ada di sekitar kita yaitu ember, arang/sabut kelapa maupun spon untuk media tanam sayuran. Lebih lanjut Dr. Ferdinan menyatakan bahwa dengan tehnik budikdamber kita dapat membesarkan ikan lele 50-100 ekor per ember kapasitas 60 liter atau tergantung ukuran ember. Idealnya dalam 1 liter air untuk hidup 1 ekor ikan lele. Pemberian pakan dapat dilakukan secara rutin 2-3 kali perhari, namun harus dalam waktu yang sama agar tidak terjadi perebutan pakan ataupun kanibalisme antara ikan lele. Dalam waktu 2 bulan ikan lele dalam budikdamber dapat dipanen. Selain ikan lele, teknik budikdamber juga dapat digunakan untuk budidaya ikan nila. Oleh karenanya teknik budikdamber sangat cocok diaplikasikan oleh masyarakat yang mulai mencoba pembudidayaan/pembesaran ikan. Berbagai peralatan dan bahan yang digunakan dalam pembuatan budikdamber seperti terlihat dalam Gambar 6.

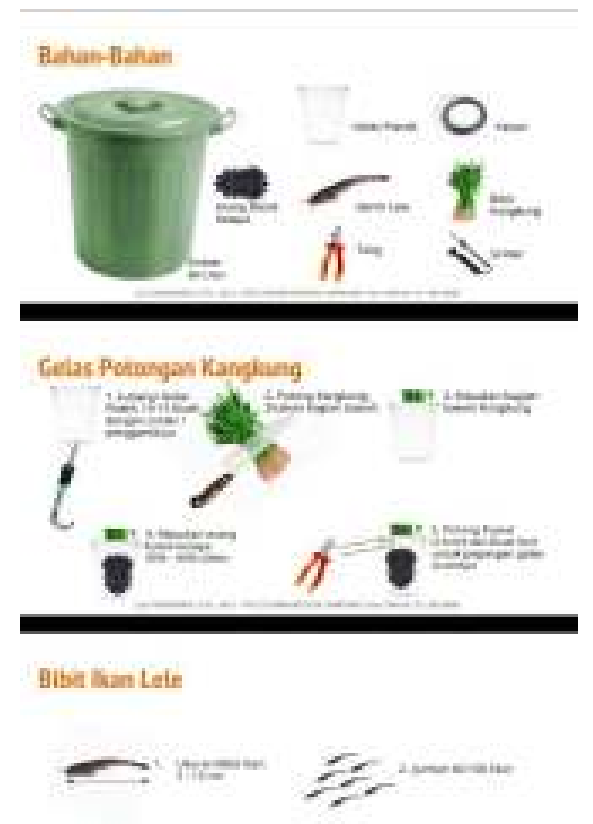

Gambar 6. Alat dan Bahan Pembuatan Budikdamber

3. Penjelasan Pengoalahan Zero Waste dan Pembuatan Pempek Pelangi

Konsep pengolahan ikan berbasis zero waste dijabarkan oleh Bapak Herpandi, S.Pi., M.Si., Ph.d. Pngolahan ikan selalu menghasilkan limbah baik berupa jeroan, sisik, dan tulang. Agar produk olahan ikan seperti pempek memiliki nilai lebih 
maka dalam proses pembuatannya dapat dikominasikan dengan berbagai sayuran dan buahbuahan sehingga memiliki warna yang menarik, yang terkenal dengan Pempek Pelangi. Selain itu pempek pelangi juga mengandung berbagai komponen lainnya yang dibutuhkan tubuh, seperti peningkatan kandungan vitamin, mineral maupun serat pangan. Pengolahan pempek menghasilkan limbah berupa jeroan ikan, sisik, dan tulang. Jeroan ikan dapat dijadikan silase untuk pakan ternak, sedangkan sisik dan tulang ikan dapat dijadikan makanan ringan berupa kripik sisik dan keripik tulang ikan.

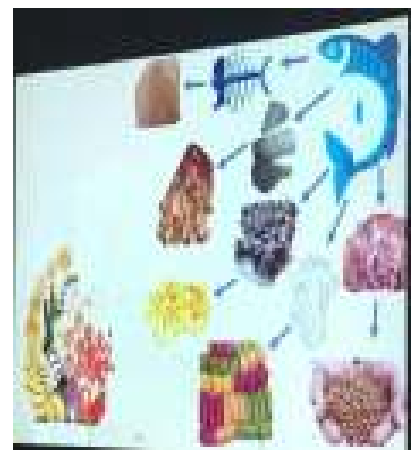

Gambar 7. Pengolahan Ikan zero waste

\section{Pemanfaatan Limbah Ikan menjadi Makanan}

Diantara pemanfaatan limbah olahan ikan menjadi makanan yaitu pengolahan keripik dari sisik dan tulang ikan. Materi pembuatan keripik sisik dan tulang ikan disampaikan oleh Dr. Rinto, S.Pi., M.P dengan disertai materi berupa leaflet pembuatan keripik sisik dan keripik tulang ikan. Contoh pengolahan keripik sisik dan tulang ikan dapat dilihat dalam Gambar 8.

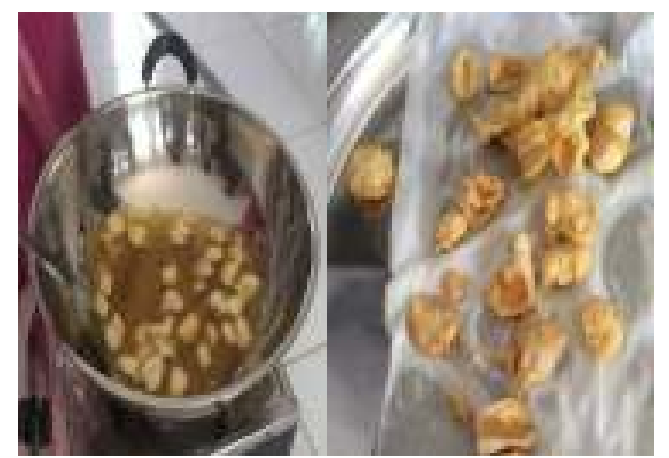

Gambar 8. Olahan Keripik Sisik Ikan

\section{Penyerahan Bantuan Alat}

Pada akhir kegiatan, masyarakat Desa Pulau Semambu diajak untuk berdiskusi secara langsung dengan melakukan tanya jawab yang dipandu oleh Ibu Susi Lestari, S.Pi., M.Si dan Ibu Indah Widiastuti, S.Pi., M.Si., Ph.D. Antusias sangat terlihat dengan adanya berbagai pertanyaan dari warga, diantaranya dilakukan oleh Bapak M. Ridwan, Bapak Gunadi, Ibu Rahmi Lidia dan Ibu Kartika Yolanda yang sangat tertarik dengan teknik budikdamber. Selain itu juga Ibu Lilik Rustianti, Ibu Evi Hartati, Ibu Ririn Novianti dan Ibu Yuniarti yang banyak memberikan pertanyaan dan sharing informasinya terkait pengolahan ikan berbasis zero waste. Agar kegiatan ini dapat diaplikasikan secara langsung maka pada kesempatan ini tim pengabdian dari Jurusan Perikanan Fakultas Pertanian Universitas Sriwijaya memberikan bantuan berupa 5 paket budikdamber, masing-masing paket berisi ikan lele (50 ekor), pakan $1 \mathrm{~kg}$, dan bibit kangkung 1 bungkus. Selain itu juga diserahkan bantuan berupa alat hand sealer packaging 5 unit yang bermanfaat bagi pengemasan produk-produk perikanan yang nantinya dapat dibuat/dikembangkan oleh masyarakat Desa Pulau Semambu.

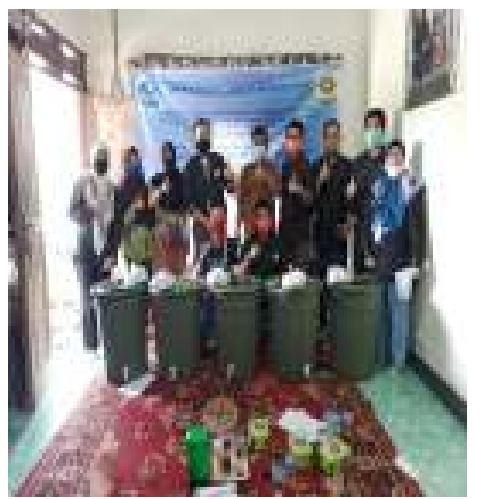

Gambar 10. Penyerahan 5 Unit Budikdamber dan ikan lele 50 ekor/unit

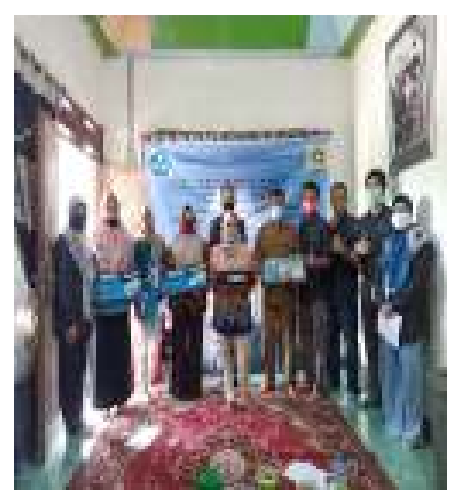

Gambar 11. Penyerahan 5 unit Hand Sealer Packaging 


\section{Sosialisasi Kegiatan Melalui Media Masa}

Kegiatan Pengabdian Masyarakat dengan

tema Introduksi teknik budikdamber pada pekarangan terbatas dan pengolahan ikan berbasis zero waste untuk menunjang pemenuhan pangan keluarga di masa pandemic covid-19 di Desa Pulau Semambu Indralaya, telah disosialisasikan baik melalui media online maupun media cetak surat kabar yang terbit tanggal 1 Desember 2020.

\section{Tribun Sumsel (online)}

https://sumsel.tribunnews.com/2020/11/30/Bahan dan Cara Mudah Membuat Keripik Tulang Ikan Gabus ala Mahasiswa Perikanan Unsri - Halaman 1 - Tribun Sumsel (tribunnews.com)

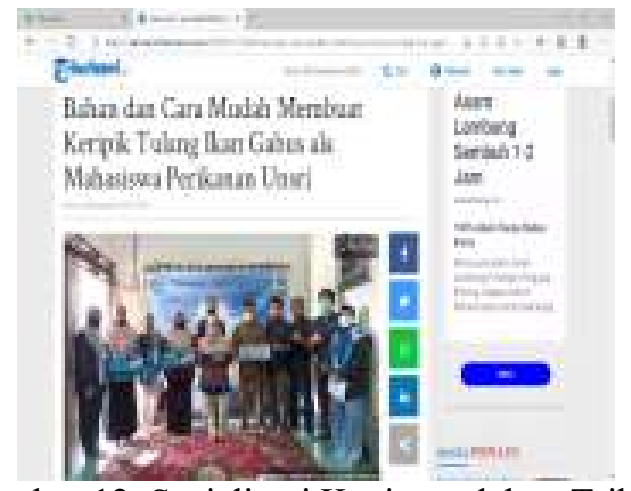

Gambar 12. Sosialisasi Kegiatan dalam Tribun Sumsel (online)

\section{Media Cetak/Surat Kabar Sripo.}

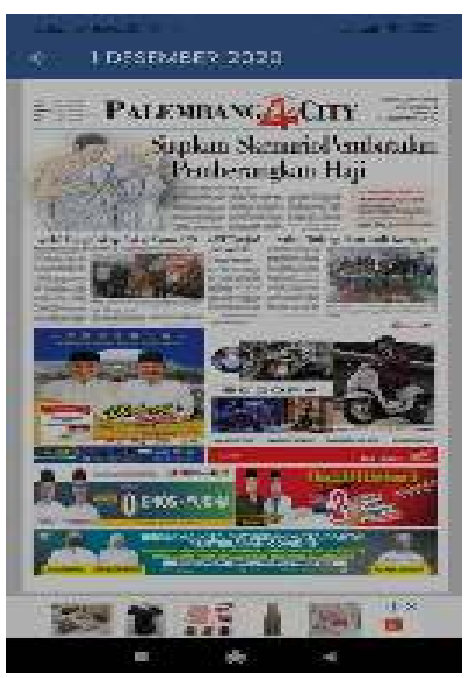

Gambar 13. Sosialisasi Kegiatan dalam Sriwijaya Post

\section{Kesimpulan}

Kesimpulan yang dapat diambil dari kegiatan ini adalah tema kegiatan pengabdian tehnik budikdamber dan pengolahan ikan berbasis zero waste diterima dengan baik oleh masyarakat Desa Pulau Semambu terbukti dengan aktivitas diskusi dan tanya jawab yang berlangsung seru dan menarik. Paket bantuan berupa 5 unit budikdamber dan 5 unit hand sealer sangat bermanfaat untuk pemanfaatan teknologi secara langsung dari materi yang disampaikan dan diharapkan dapat memacu masyarakat untuk dapat mengaplikasikan ilmu/teknologi yang iperoleh.

\section{Ucapan Terimakasih}

Ucapan terimakasih disampaikan kepada Universitas Sriwijaya, yang telah membiaya kegiatan ini melalui pendanaan Dana PNBP Universitas Sriwijaya. Sesuai Dengan Surat Perjanjian Penugasan Tenaga Pelaksana Pengabdian Kepada Masyarakat Skema Desa Binaan Universitas Sriwijaya Tahun 2020 Nomor: 0017.20/UN9/SB3.LP2M.PM/2020, Tanggal 23 Oktober 2020.

\section{Daftar Pustaka}

Mukti, R.C., Amin, M., Wijayanti, M., Yulisman, Octaviani, $\mathrm{R}$ dan Pangawikan, A.D. 2020. Pemeliharaan Ikan Patin dengan Pemberian Pakan Tambahan DI Desa Pulau Semambu, Kecamatan Indralaya Utara, Kabupaten Ogan Ilir. Logista Jurnal Ilmiah Pengabdian Kepada Masyarakat, 4 (1): $25-31$.

Nursandi, J. 2018. Budidaya Ikan dalam Ember "Budikdamber" dengan Aquaponik di Lahan Sempit. Prosiding Seminar Nasional Pengembangan Teknologi Pertanian Politeknik Negeri Lampung: 129-126.

Wida, E dan Anam, C. 2016. Peningkatan Kualitas Dan Diversifikasi Produk Olahan Ikan Lele. E-Dimas Jurnal Pengabdian Kepada Masyarakat, 07 (02): 27-38.

Widyatami, L.E dan Wiguna, A.A. Teknologi Pengolahan Ikan Lele secara zero waste menjadi Produk Olahan Kerupuk pada Ponpes Raden Rahmat Sunan Ampel Di Kabupaten Jember. Prosiding Seminar Hasil Penelitian dan Pengabdian Masyarakat Dana BOPTN 2016: 3-7. 